\title{
Stillness in Locomotion and Self-dissolution of Metropolitans in Bowen's To the North*
}

\author{
Yena Wang \\ School of Foreign Languages, Shanghai Institute of Technology, Shanghai, China
}

\begin{abstract}
This article is to justify that modern metropolitans suffer from the dissolution of identities and a loss of loving ability to be a modern man of complete personality. Motion and stillness, life and death coexist within the same urban space of metropolitans. And the stillness in urban life space is both the cause and effect to accelerate the process of self-dissolution of metropolitans. The identities and autonomy of Bowen's city dwellers are formed and destroyed in the process of moving. Bowen represents the metropolitans' predicaments of self-dissolution during interwar London by setting them in a depressing space of constant travels and emotional stillness in locomotion. The crazy mobility brings the destructive outcome to make its subjects into the absolute stillness and self-dissolution of the subjects, which is also a common living state of modern city dwellers. This article tries to bring an awareness as well as to show a sympathetic feeling towards those predicated modern man.
\end{abstract}

Index Terms -Elizabeth Bowen, To the North, stillness, locomotion, self-dissolution

\section{INTRODUCTION}

Elizabeth Bowen's explorations of going and leaving, arriving and departing "dislocate the identity of the self, the very conception of society, love and all friends and relations" (Bennett, Andrew and Royle, 1995, p.31). Here the writer involves the term "locomotion" to indicate the ability to move and predict a loss of power in mobility. It is more often used as a biological term to describe the move of animals, muscles, robots etc. Gilles Deleuze implements an association between bodily and linguistic locomotion in interpreting Samuel Becket's works in L'Abécédaire, a filmed interviews with Gilles Deleuze, directed by Pierre-André Boutang in 1996. And the term is more and more employed in literary fields for its psychological indication. Jacqueline Woodson, a young writer of the United States who was awarded National Book Award entitles her novel Locomotion (2003). Hilary Strauch employs this word to describe mobility driven by carriages in his 2012 essay "Carriages and Mobility in Jane Austen's Novels". This juxtaposition of stillness with locomotion is to make a correlation between the two. Nevertheless, if movement must be sought, stillness must inevitably lie in wait. Implicit in the mobility is the immobility, and vice versa. As Deleuze state in his Francis Bacon: The Logic of Sensation: "Following the law of Beckett or Kafka, there is immobility beyond movement: beyond standing, there is sitting, and beyond sitting, lying down, eventually to melt away" (Bryden, p.153). There is a dialectical relationship between the two with stillness in essence.

\section{STILLNESS AND LOCOMOTION: LIFE AND DEATH}

The city space of London is stilled by strike of wars and modern materialism. Time and space interweaved London becomes the site for most of Bowen's fictional scenes, where the mobility and stillness are displayed. The metropolis is not only a setting for action and stories, "it expresses and conveys beliefs about life society" (Crang, p.49). The end of the $19^{\text {th }}$ century is filled with new experiences of urban modernity with technical inventions and social upheavals. Experiencing wars, the 1920's London is more a traumatic city with a rising feeling of despair, loss of hope and anxiety. The city becomes a locus of the isolated subject, and it "equally has to do with one's 'self', one's identity or being and one's location" and "location or context determines who one thinks one is, and how the subject is oriented or disoriented not only in the present but in relation to the past, to personal, and to cultural memory" (Wolfrey, p.170). It is no different from the other cities unlighted and waiting among their ruins under the moon, filled with noise and transport. Here it becomes a space of death and stillness during wartime, where the dead continues to haunt the living ones. It "reproached those left living" (Bowen, 2002, p.165) and is felt as an effect in interwar and war time scenes.

Motion and stillness, life and death coexist within the same urban space of metropolitans. Metropolitans try to maintain their home-belonging and identity in the fluidity of city life, but to find the dissolution of self finally. As Simmel's points in his "The Metropolis and Mental Life", the metropolitans' "deepest problems of modern life" lie in their "claim to preserve the autonomy and individuality of his existence in the face of overwhelming social forces, of historical heritage, of external culture, and of the technique of life" (Simmel, p.47). This philosophy of living generates

\footnotetext{
*Fund Information: This paper is funded by the project "Science and Technology Development of Talents" of Shanghai Institute of Technology (Project Name: Research on Communal Predicaments and Spatial Representation in Bowen's Novels; Project No. : ZQ2020-26).
} 
a stillness of metropolitan psyche which signifies an atmosphere of death emotionally of modern life. When an atmosphere of death invades the houses, there is always a space of stasis: Windsor Terrace of Anna and Thomas in London in The Death of the Heart and the house of Stella in The Heat of the Day etc. With underlying impetus of wars, death becomes the center of stillness in metropolitan cities like London.

In whatever forms of locomotion, the characters remain stillness in two ways: the circular locomotion and emotional stillness. In this sense, characters are in mobility but essentially in stasis. The two polar binary of passion co-exists in modern life of the 1920s London, where fire meets ice and Eros reveals itself as Thanatos. Although with different ending story, both Cecilia and Emmeline are always on the move, especially Cecilia's yearning for traveling and strangeness enacts a jittery desire to escape this center of stillness. Lady Waters is anxious about "Cecilia's perpetual rushing abroad and then home": "it is a pity she cannot settle" (Bowen, 2006, p.14). She considers her mobility "neurosis". She can never settle her down and once she settles in the house, she is out of order into a state of hysteria. After "Cecilia resumed home life at high pressure", "once or twice, a shadow passed over" her face and "tears in her eyes, dropping sodden envelopes onto the bath-room floor" (p.30). Language becomes interrupted and not coherent. Her self is split into pieces. This is something more than the restlessness which Lady Waters identify as a social affliction. They try to ensure their identity in the course of moving, but find no way to escape their original point. Whatever state they are in, it cannot stop the dissolution course of their identity. Emmeline's final self-destruction is its extreme expression. Identity comes into zero when travel comes to the halt in the car crash and Emmeline becomes nothing, leaving some traits of wound to the living ones.

The traveling course of going back and force is often in a circular pattern, which indicates a relative state of stillness in locomotion. This circular pattern of moving is a metaphoric display of the city dwellers' emotional stillness. The utopian nature of their heterotopias destroys the dream bubbles of the metropolitans. They move everywhere in corners of the city but to find them trapped in the starting point and remain emotionally still. Modern transport enables the characters in the novel to be motionless in motion, driven by machines that should be made use of instead. Most of the motion in To the North is circular except for the final drive to the North with Markie as the only one-way journey. The railway travel of Cecilia is coming back to London from Italy; the flight to Paris of Emmeline brings her back to her Woburn Place office after a circular flight; the short travel to Farraways and Connie's cottage is a going and coming tour in both directions. Relatively speaking, wherever they move, they come back to the starting point so that it seems they have never moved. Cecilia frequently announces to go to America, yet she never sets out. This travel is just a dream like trip taken on lips and in mind. The driving course between home and the travel bureau also draws a circular line, indicating that the everyday life of Emmeline remains at the same place wherever she goes. Bowen's Metropolitans like Cecilia and Emmeline intend to establish identity as a compensation for their state of orphanage, but finally in every circular of travel, they sink into a more serious state of losing it.

\section{The DePRESSING SPACE AND INCAPABILITY OF CitydWELLERS}

The depressing space in metropolis functions in defining and dissolving the metropolitans' identity. The Cultural Geography tries to define identity by where we live, as well as the common definitions by who we are and what we are not. "Linking with ideas of territory and attachment to place", Crang explores "how relationships over space become involved in defining group identities" (Bowen, 2006, p.61). Surviving through the impetus of recent great wars and transport revolution, Bowen's city dwellers bear the typical metropolitan characteristics. Dwelling in modern cities during wartime years, they are prone to modern transport, liable to feelings of alienation and rootlessness, suffering a strong sense of loss and anxiety for an uncertain future. Bowen's problematic metropolitans are defining and losing their identity in a process of mobility and stillness in metropolitan cities. Bowen expresses the anxiety upon the metropolitan life represented by high developed transport system in London by quoting the vicar of Faraways in To the North to speak: "modern life becomes increasingly complex" and "it seems a short time since motoring was in itself a pleasure". In his opinions, "the whole incentive motoring seems an anxiety to elsewhere" (p.78). Not a modern figure in the era, the vicar feels secured without movements everywhere. Little amusement at Farraways: not wireless, no swimming pool, nothing", he "feels sure" (p.78). With a questioning of selfhood, Bowen's problematic metropolitans are searching for a certainty of identity during their course of travel between places in metropolitan cities. They take efforts to set themselves in knot of the transport network to make certain who they are, where they are from and where they would go. In her narrative of every failure of certainty and identity, Bowen conveys modern sensibility as despair, irresolution, and dislocation of the traveling community in To the North.

The dwelling space of Markie is closed, queer, dark and sinister, where sun does not shed light, imposing the inhabitants alienated and alienating. Its sinister, dismal and depressing quality is more like a disease and it gets a power to infect Markie, who is to destroy Emmeline little by little. It has the power to rob the vitality of humans and depersonalize them. The dwellers and the dwelling space become one entity as time grows and the inhabitants are made sinister and wicked like the container itself, disabled in social and love relations. This space is also a modern metropolitan production during wartime years. Separated from his sister's in a "very high, dark-red" house in Sloane Street, Markie's sinister flat is "completely cut off" from his sister's world below (p.80). Its hall is "darkish" and "the only light filters down through the banisters from a much higher floor" (p.81). He and his sister "make a point of not meeting, cut each other's friend at the door, had separate telephone numbers and ask no questions". His meals are 
"separately cooked" and "went up to the top in a service lift" (p.80). The way of communication with the cook is whistles through a pipe and the dumb waiter. Such an abnormal way of life has shown his neurotic problem, which betoken the final tragedy in the last chapter. The Gothic atmosphere depersonalizes Emmeline when she comes to visit the dwelling space the first time: "in her long yellow dress, like a ghost astray" (p.81). Its shadowy corners and its invisible cook whose "reedy, ghostly whistle" makes Emmeline jump (p.84). In the dim light of Markie's flat, she feels self-reproachful, nervous, and feared. Markie is the master and authority of this sinister dark space in his coldest and most aggressive manner, Emmeline is bewildered and dares not meet Markie's eyes. Emmeline is reduced so silent and low-down that she has to agree with him at anything.

Cecilia's afternoon in the death space is a terrible thing, bringing her into hysteria of depression, gloominess, and despair. Bennet and Royle see the shivering peculiarity in a broader sense of space and time in Bowen: "what is fragmented or 'shivered' is not only Emmeline's experience or state of mind: it is shattering or shivering that can be seen to characterize any and every Bowenesque afternoon, or more precisely, that haunts and thus conditions all 'place and time' in Bowen" (Bennett, Andrew and Royle, p.31). With "the sun, forgetting decline", this afternoon is "no afternoon", and time halts into a state of stillness (Bowen, 2006, p.146). In such a time which is also no time at all, Bowen's female protagonists fall easily into a state of self-exposes of emotions and personalities. In a gloomy and silent atmosphere, they fall into a state of depression and hysteria, with fragments thoughts and speech. Locomotion cannot stop their emotional stillness. Cecilia has lost the ability to love completely, and Julian, the man whom Cecilia accepts for marriage without love, is also unable to form any relationship based on true feelings. Perhaps neurosis is the last courage for her to live in the world.

For the restless Cecilia, once she loses such ability and the travel comes to its original point, she often falls into a "neurosis" breaking-down (p.14). Like Simmel's metropolitans, she refuses to response to the outer stimulates with heart. But when she resumed home, her head stops to react rationally. In the death center of Henry Summers, "melancholy invaded her", "tears in her eyes" and "she is half dead" (p.30-31). Forgetful, doubtful and incoherence of speech, Cecilia is often in a state of mental problem. What's more, nervousness is not unique for human beings. The luckless little white dog of Lady Waters' is "nervy". "He belonged to the house and desolated by too many departures dared form no more attachments, looking at newcomers with a disenchanted eye (p.193). No matter Cecilia or Emmeline, who are feverishly moving and escaping the death center, they find at last they never moved any step from the house at all. They just behave like transport system to go and come back to the station. The final car crash reaches to its climax in this neurotic disturbance of the metropolitans which causes the dissolution of identity into nothing. The crazy mobility brings the destructive outcome to make its subjects into the absolute stillness. The death brings Emmeline into a conjunction with Henry into oneness completely. The only one-way travel leads to death and Cecilia is constrained forever in the house of Oudenarde Road waiting for an impossible return of Emmeline.

\section{The Disolution OF IDENTITY}

According to Simmel, "rationality", "calculability" and "exactness" are required by the complications and extensiveness of metropolitan life, which leads to a consequence "blasé attitude" (Simmel, p.51). It is a consequence of having hardened oneself to the shocks of everyday existence, and the price paid for surviving the nonetheless constant onslaught of sensual stimuli in the metropolis, resulting in an "incapacity thus emerges to react to the new sensations with the appropriate energy" (p.51). Baudelaire's employs "Ennui" to describe inability to feel of the "ugly and abortive" beast of the modern mind, which is very appropriate to interpret Simmel's blasé attitude of city dwellers. Aesthetic deadening of the senses goes hand in hand with the moral indifference and mental dullness. They appear to the blasé person in a homogeneous, "flat and gray tone" with no one of them worthy of being preferred to another (p.52). They are experiencing meaningless in a way which is beyond repair. They are all floating "in the constantly moving stream of money" (p.52). Cecilia parallels with Simmel's blasé person with Baudelaire's "Ennui" way. With a sense of "spoiled summer", Cecilia feels "life was escaping her" with so much prettiness wasted, darkly spread like spilt ink" (Bowen, 2006, p.219). The streets of London "were to be navigated and parks desolate, pleasure-boats under tarpaulin and bands silent". This is a scene of wasteland of London, and the Metropolitans like Cecilia, who survives the war and disease (not like her two dead soldier brothers and her husband died of pneumonia), is not living a pleasant life, but a life-in-death. London "became a mesh of unwilling hurry where nobody smiled or lingered" (p.220). Like "the moon diminished, wasting itself upon vapors the sun smiled on", Cecilia is leaving her petals withdraw little by little in the restlessness of life.

Governed by a traumatic past and suffering from an anxiety for future, the city dwellers are hard to get some emotional development. The loss of love and living ability makes them live like ghosts without souls. Simmel assumes such a stillness is "to preserve subjective life against the overwhelming power of metropolitan life", but at the same time it generates an inability to love the self and others (Simmel, p.48). Governed by the death center in house of Oudenarde Road, both Cecilia and Emmeline are robbed vitality and personality to leave their own life. Back from her trips, she is a woman who cannot stay alone in the depressing space in the house. She often falls into a state of hysteria during sunset; there is a sense of oneness between Emmeline and her dead brother in many ways. Her identity is reduced little by little by the two beloved men in the world, the dead brother Henry and the sinister lover Markie. Solitude and stillness is an immortal emotional state which cannot be broken, and both of them can nothing to rescue 
themselves.

Henry's death is a metaphor of the decadence of metropolitan London, which provides enough excuses for the emotional astray of the city dwellers. Time and space becomes halted in Henry, whose death brings a stilled and suspended time in To the North. His wife Cecilia and sister Emmeline are put in stagnation by the death center formed by Henry's death photo, which signifies not only as an emotional wounding of Cecilia and Emmeline, but also a likeness of their emotional stillness. This is a space of death and "the place was a morgue", where "the red roses lost color" (Bowen, 2006, p.20). The space of the house was occupied by Henry, whose photograph is on the mantelpiece, watching every move of his wife and sister. His sudden decease of pneumonia leaves Cecilia a "widowed shepherdess with only the clock to smile at" (p.20). The world of Cecilia after Henry's death is a depressed one and she has lost the ability to love any man in the world. Cecilia lies with a "ghost" of Henry who "was with her casually, as though he came strolling into the room" (p.45). She tries to flee the dead center and urges to found relations of occasions during her travel. She confessed to Lady Waters that "I can't help talking to people in trains" (p.274). But any travel ends finally by it staring position in the house. For Cecilia, mobility is the refusal of the literal dead center of the house full of the staring of the photograph and the coffer of ashes, which memorized the stagnation of life and emotions.

Emmeline is fatally put into stagnation by her brother's death. But unlike Cecilia who tries to flee, Emmeline is pulled and magnetized into the dead center. In addition to her orphaned state and sense of not-belonging, the intrusion of Markie accelerates her course of dissolution of her identity into the one of her lost brother. There are many ways of Emmeline's identity disintegration till the final absolute loss of life in the end. The first course of the dissolution course is her quality of nothingness. Emmeline is often described as transparent with "a transparent skin" and "erratic" (p.53-54), like "a vapoury shadowless thin cloud over a tree" (p.67). She gets little sense of existence and communal relations. Although meeting each other every day in the office, she "knew nothing and wished to know nothing of Peter's life" (p.37). Such a policy of life is not only the presentation of her personality of goodness or innocence, but as a modernist "inability to engage oneself closely with life on any terms" (p.34), a kind of nothingness of the self. She stands like "a stranger in her own home" and it is "already as though she did not exist" (p.184). Often dressing herself in silver, she is associated with objects with reflective surfaces: mirrors, glasses, windows, ice, all of which show a quality of nothing. Her happiness is "like an immortal bubble, touching a moment objects it seemed to enclose" (p.225). On the night of the final drive, she is dressed in silver, which dazzles Markie and "glittered past him" like a northern star, "very tall, silver and shining" and "her hair tonight at its brightest, face as its most translucent". That makes Markie wondering "were she dead" and "she could not have come from farther away" (p.284-285). This nothingness quality foresees her final nothingness of life and identity in the crash.

Her nothingness is enforced by her silence and lack of personality in relations with Markie. Emmeline loses her voice and vitality upon the imposing and irritable Markie. With Markie, "she was very silent" and she feels "speechless so often", as though she "were climbing a mountain" (p.226, p.240). Their relationship is doomed also by the contradiction between female professional expansion and male's sexual containment. Between the wars, Emmeline embraces the social advantages opening up to women, while Markie ridicules career women and expects feminine submission. Emmeline is reduced to a loser as a career woman and to death as a female driver. In contrast with her shininess, Markie embodies the darkness invading the innocence of Emmeline. Markie bears all the marks of modern city man with the "blasé attitude" Georg Simmel ascribes. He is the egoists of metropolis, sinister, selfish and irresponsible. He resembles much with the caddish Eddie in The Death of the Heart; however, who are the typical male of the period who worships female purity but still wants women to be sexually available for his needs. But to their own capabilities, like Eddie and Brutt, Markie is one of the useless young men who can fit themselves in none of the spaces and family is the last destination in the world for them to dwell in. The only function of existing is to wither by himself and to destroy others. The absurd closed space of the flat forms "a dead center" for Emmeline like the one of Oudenarde Road for Cecilia.

The disintegration of her identity lies secondly in her uncertainty of sexual identity. The seduction in the hotel room in Paris and in the garden of the house on Oudenarde Road is the beginning of Markie's invasion of her private space. Markie lacks the qualities she needs in a lover and she surrenders to Markie in their relations in many ways. Markie "hates moving" (p.180) and "mobility was not present in Markie's expression and attitude" (p.176). Markie finds Emmeline's unselfconscious passion overwhelming and her intensity disrupts his ability to live a detached existence. Markie views Emmeline's passion as threatening to his emotional stagnancy. His irrational fear of Emmeline underscores his own limitations in emotional and sexual matters. In Markie, "under the fairly imposing surface of his masculinity there whirled currents of instability" (p.180). This "paradox of intimacy and isolation" rushes into Emmeline. The sexual aggression is followed with a withdrawal from her. He reassures to Emmeline that "I couldn't live with you", "it is impossible" and "we could not marry" again and again (p.171, p.186, p.187). With typically limited and fragmentary understanding, the literally near-sighted Emmeline focuses on Markie's shreds of decency and conscience, willfully gives herself up to his hypocrisy and selfishness. She believes that "nobody wants to marry me" (p.243) and begs for his love by announcing "I love you" and "I give in, I give up" (p.262). Her surrender to Markie makes her identity dissolve little by little and in return Markie repays her with his affair with Daisy, the former mistress of Markie.

Emmeline's oneness with the deceased Henry, who shares the same qualities of stillness and ghostliness with her, provides the essential drive for the dissolution of her identity. Bowen finds the habitat for the ghost of Henry in 
Emmeline, to allow them coexist in the house of Oudenarde Road. Her qualities of quietness, nothingness and tranquility make her a suitable host for the dead soul. Emmeline is the ghostlike apparition of Henry. The boundary between the living and the dead is easy to penetrate. Henry is the living dead and Emmeline bears "death-in-livingness" (Gildersleeve, p.16). Such an oneness seems to indicate that the inhabitants are neither living nor dead; and it suggests that Emmeline may be caught in the repetition of, or haunted by the fate of her brother. Her physical state mirrors her psychological disintegration. In the afternoon of Henry's death center, Emmeline "moves by proxy while remaining at a standstill", "static as the eye of a tornado" (Ellmann, p.103). So in the final act of the novel, Emmeline meets her own ghost, which is also her brother's in the car crash. Her death reduces her to nothingness and allows her reunion with Henry. Emmeline unifies the destruction of her body with her psychological wound, with the oneness between Emmeline and Henry accomplished. Emmeline's stillness could also be read as a means of self-defense, to provide protection from further wounding. It is similar to the way Anna Quayne's death sleep condition in face of marriage crisis. Here is a typical psychological condition of those who reconcile with the First World War. And her rush for death in the last chapter is also an escape from the dead space and to make herself against further hurt by Markie.

The final stage of her disintegration of identity is her final death, which brings the course of dissolution to the extreme form of nothingness. The stilled depressing space has invaded her with a sense of death and the oneness between Emmeline and Henry indicates the proceeding death scene. It is Henry or death, which is "something unknown" accompanying her "formlessly" (Bowen, 2006, p.224). She feels that "the room kept for her the ghost of its early strangeness" and it is "becoming familiar"; and "something unknown came through" (p.223). The sense of "strangeness" is becoming more and more familiar. This is a psychic dissolution which precedes her physical death, predestined when Cecilia looks into Emmeline's room in one of the Bowenesque fatal afternoon after a lunch party. There is "emptiness" and silence in the room, which is "like a death chamber", and "the sleeper seems many times to have died" (p.164). Emmeline here is symbolically dead. Her unreality and non-existence emphasizes her likeness with Henry's ghost with whom Cecilia lies with. At last, she lives "with nobody", the dead Henry and falsely living Emmeline (p.165). This hallucinatory psychosis in this passage foreshadows the closing moments of death in the end of the novel, in which Emmeline speeds to death: her desire for dissolution, for freedom from pains and for survival. Among the three Summers, Cecilia is the only survivor, who is condemned to live in the orphanage under the shadow of death.

The death in the hysterical driving is the ultimate state of Emmeline's stillness and nothingness, which ends the process of her self-dissolution. It indicates a physical and emotional extinction, suggesting a complete erasure of life and impossibility to return. Here in the last drive of death, the personality and identity of the city dwellers are reduced into zero. The last car-driving to Baldock in the end of the novel brings an association with Browning's "The Last Ride Together" in Men and Women (1855): "Who knows but the world may end to-night?" It is like going beyond "one's last day on earth when fear and all sense of farewell had alike departed and only a very brief transit remained ahead" (Bennet, Andrew and Royle, p.40). At this crazy driving, the human beings are utterly controlled by motion till the ability of locomotion is reduced to nothing. Emmeline cannot control the motor car, as well as herself, and she surrenders to her car to let it go out of control. The speed possesses her and "the car hardly holding the road seemed to him past her control" (Bowen, 2006, p.298). With "a drop in her voice, less resolution than deadness", everything is over and it seems that her silver fabric of her blouse melts into nothing. Night silence and stillness of death embrace the dying people: "a sense of standstill, a hush pervaded this half-seen country" (p.301-02). At the death edge, she can feel nothing and sees "TO THE NORTH" written black, with a long black immovably flying arrow on the white board. Bowen symbolizes her death by the road sign and she employs the word "levitation" to indicate the total loss of identity: "for this levitation a total loss of her faculties, of every sense of his presence... she was lost to her own identity, a confining husk" (p.304). Bowen ever laments for her death: "Poor Emmeline! It was inevitable" (Glendinning, p.95). Emmeline's death in the car crash is no accident but the inevitable result of the loss of identity of metropolitans during interwar London. The identity of Emmeline as a London urbanite is dissolved totally into nothing.

\section{CONCLUSION}

To sum up, Bowen represents the metropolitans' predicaments of self-dissolution during interwar London by setting them in a depressing space of constant travels and emotional stillness in locomotion. In a busy, noisy and mobile urban space, the metropolitans are prone to modern transport, liable to feelings of alienation and rootlessness, suffering a strong sense of loss. Bowen's city dwellers are such a community of London metropolitans, defining and losing their identity in a process of mobility and stillness in an era of wars. With a traumatic history of the unnamed First World War, they try to settle down in cities and travel to define their identities. However, wherever they live, the dwelling space is occupied by death and darkness. Driven by modern transport and communication, they set themselves in constant trips by trains, cars, airplanes etc. and they are always longing to live in other places to escape from the dead center occupied by the traumatic past. They strive to search for a spiritual home and set her identity by establishing some relationship with the surroundings. The constant and never-ending travel is their everyday living state in exile and rootlessness is still the everlasting predicaments for the London dwellers. Any travel courses are proved to be in a circular pattern and they can hardly stop the atrophy of self and dissolution of identity of the metropolitans. The final car crash reaches to its climax in this neurotic disturbance which causes the dissolution of identity into nothing. The crazy mobility brings the 
destructive outcome to make its subjects into the absolute stillness. At this point, the human beings are utterly controlled by motion till the ability of locomotion is reduced to nothing. Bowen's modern people suffer from the predicaments of dislocation in such an urban space both in mobility and stillness. Her characters can only find peace when their identities become nothing in death. Even in the most intimate domestic spaces, alienation is still their everyday living state for modern people during interwar time London.

\section{REFERENCES}

[1] Bennett, Andrew and Royle. (1995). Nicholas. Elizabeth Bowen and the dissolution of the novel: still lives. London: Macmillan Press.

[2] Bowen, Elizabeth. (2006). To the North. New York: Anchor Books.

[3] Bowen, Elizabeth. (1962).Seven Winters and Afterthoughts. New York: Alfred. A. Knopf.

[4] Bowen, Elizabeth. (1986). The Mulberry Tree: Writings of Elizabeth Bowen. Ed. Hermione Lee. London: Virago.

[5] Bowen, Elizabeth. (1984). Bowen's Court and Seven Winters: Memories of a Dublin Childhood. London: Virago.

[6] Bowen, Elizabeth. (2008).People, Places, Things. Edinburg: Edinburg University Press.

[7] Crang, Mike. (1998). Cultural Geography. London \&New Yok: Routledge.

[8] Foucault, Michel. (1986). “Of Other Spaces.” Trans. Jay Miskowiec. Diacritics. 16.1, 22-27.

[9] Gill, Richard. (1987). "The Country House in a Time of Troubles.” Elizabeth Bowen. Ed. Harold Bloom. New York: Chelsea House, 51-62.

[10] Lytovka, Olena. (2012). "The Uncanny House in Elizabeth Bowen’s Fiction.” Leitura Flutuante. No. 4, 85-97.

[11] Natsumi, Amano. (2003). "Memory and the House in the Fiction of Elizabeth Bowen." Reading. 24, 206-215.

[12] Simmel, Georg. (1950). "The Metropolis and Mental Life." The Sociology of Georg Simmel. Trans. Kurt H. Wolff. Ed. Richard Sennett. Glencoe, Illinois: Free Press, 47-60.

[13] Strauch, Hilary. (2012). “Carriages and Mobility in Jane Austen's Novels.” Senior Capstone Projects, 116.

[14] Urry, John. (2000). Sociology Beyond Societies: Mobilities for the Twenty-first Century. London: Routledge.

[15] Urry, John. (2004). "Connections.” Environment \& Planning D: Society \& Space. Thousand Oaks: Sage Publications Inc..

[16] Wolfreys, Julian. (2008). "The Urban Uncanny: the City, the Subject, and Ghostly Modernity.” Uncanny Modernity: Cultural Theories, Modern Anxieties. Ed. Jo Collins and John Jervis. Basingstoke and New York: Palfrave Macmillan, 168-80.

[17] Wolfreys, Julian. (1998). Writing London: the Trace of the Urban Text from Blake to Dickens. Houndmills, UK: Palgrave Macmillan.

Yena Wang was born in Linyi, China. She received her PH.D. degree in Shanghai International Studies University, China in 2018. She is currently an associate professor in the School of Foreign Languages, Shanghai Institute of Technology, China. Her research interests include British and American literature, comparative literature etc. 